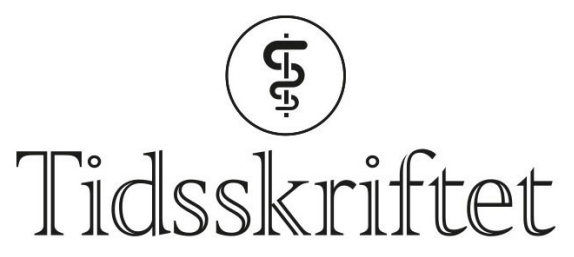

DEN NORSKE LEGEFORENING

\title{
Barn som bor høyt, blir lavere
}

FRA ANDRE TIDSSKRIFTER

KRISTOFFER BRODWALL

Barne- og ungdomsklinikken

Haukeland universitetssjukehus

Barns lengdevekst er dårligere jo høyere over havet de bor, helt fra fødselen av.

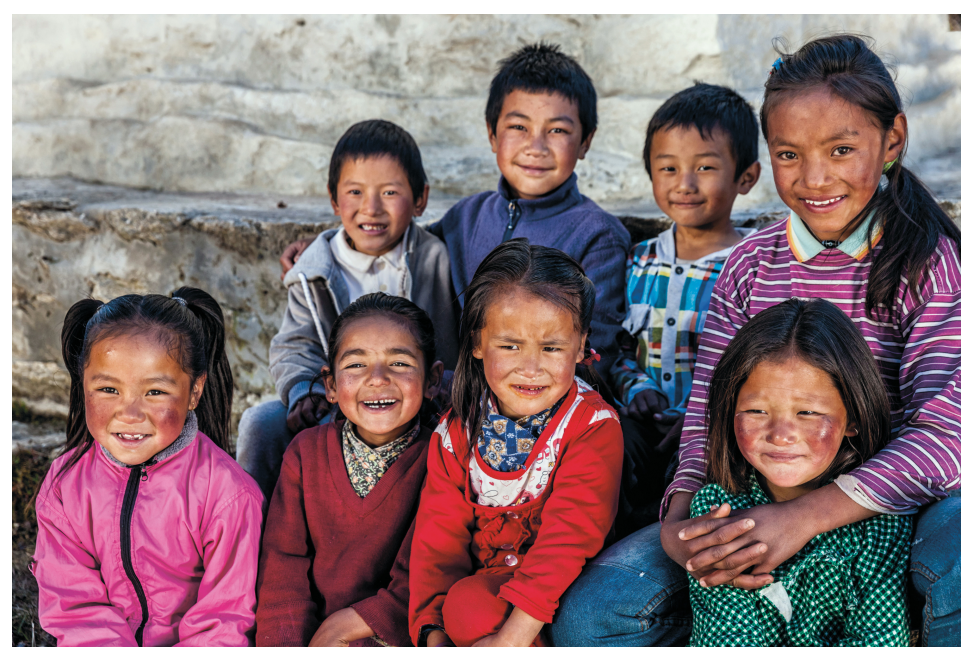

Illustrasjonsfoto: hadynyah/iStock

Andelen barn med sviktende lengdevekst (engelsk: stunting) brukes bl.a. for å evaluere befolkningers ernæringsstatus. En fersk studie viser at veksten også påvirkes av hvor høyt over havet barnet bor (1).

Studien baserer seg på data fra 133 regionale undersøkelser i 59 lav- og mellominntektsland med nesten en million lengdemålinger av barn og med bosted som varierte fra under havoverflaten og opp til nesten 6 ooo meters høyde.

Omkring $12 \%$ av jordens befolkning bor mer enn 1500 moh., og to tredjedeler av disse bor $\mathrm{i}$ Afrika eller Asia. Barn som bodde mer enn 1500 moh. var i snitt signifikant kortere enn andre barn allerede ved fødselen. Som gruppe innhentet de aldri sine jevnaldrende i høyde. Lengdeveksten var dårligere jo høyere barna bodde.

Sammenhengen mellom bohøyde over havet og lengdevekst har blitt funnet i flere mindre studier tidligere, men det har vært diskutert om dette skyldtes dårligere ernæring eller økt sykdomsforekomst i høyden. Den aktuelle studien omfattet derfor flere analyser med justering for konfunderende faktorer, slik som familieøkonomi og sanitærforhold. Det ble også undersøkt om bohøyde var assosiert med amming eller symptomer på sykdommer som kan påvirke veksten. Dessuten gjorde de en subanalyse med kun barn med gode oppvekstsvilkår, dvs. barn født på sykehus og som var vaksinert, hadde gode sanitærforhold 
og foreldre med relativt høy utdanning og god økonomi. Alle analysene talte for at høyden over havet var den avgjørende faktoren for lengdevekst. Forfatterne mener dette kan skyldes at kronisk hypoksemi hemmer normal vekst.

- Det er ingen ny kunnskap at barn som vokser opp høyt over havet, har nedsatt lengdevekst, sier Pétur Benedikt Júlíusson, som er avdelingsdirektør ved Folkehelseinstituttet og barnelege med hovedansvar for vekstkurvene vi bruker i Norge. Han mener at metodologien og størrelsen på denne studien gjør at man nå med større sikkerhet kan fastslå at det er en årsakssammenheng.

\section{LITTERATUR:}

1. Baye K, Hirvonen K. Evaluation of linear growth at higher altitudes. JAMA Pediatr 2020; 174. doi: 10.1001/jamapediatrics.2020.2386. [PubMed][CrossRef]

Publisert: 22. oktober 2020. Tidsskr Nor Legeforen. DOI: 10.4045/tidsskr.20.0739

(C) Tidsskrift for Den norske legeforening 2020. Lastet ned fra tidsskriftet.no 